7. Reprod. Fert. (1969) 18, 265-273

\title{
POST-IRRADIATION CHANGES IN SERTOLI CELLS
}

\author{
NIRMAL K. KOCHAR* AND A. J. BATEMAN \\ Department of Cytogenetics, Paterson Laboratories, \\ Christie Hospital and Holt Radium Institute, Manchester 20, England
}

(Received 7th March 1968)

Summary. Testes of mature male mice were irradiated with a single dose of 1000 rads. Enumeration of the Sertoli cells at different intervals showed an increase in their number per $\mathrm{mm}^{3}$ of tubule, but after the application of correction factors there was an immediate fall in the total Sertoli cells per testis which later stabilized at about half the preirradiation level. There was a reduction in the mean number of chromocentres per Sertoli cell, owing to a relative increase in the number of nuclei with one chromocentre, 14 days after irradiation.

It was further seen that labelled spermatocytes were transformed to restitution cells at the time that unirradiated spermatocytes would have produced spermatids. Seven days later the label appeared in spermatozoa. This implied that the restitution cells were not eliminated but were transformed to spermatozoa and the time-table of events was similar to that in normal spermiogenesis. No label appeared in Sertoli cells.

The number of grains present in spermatocytes and restitution cells and spermatozoa was nearly the same, indicating no intervening nuclear divisions.

Enumeration of the number of surviving labelled cells confirmed preleptotene as the most sensitive stage of spermatocytes.

\section{INTRODUCTION}

The sensitivity of the germ cells in the mature testis varies greatly (Heller, 1948; Oakberg, 1955; Gunn, Clark \& Anderson, 1960; Jones, 1960), but the Sertoli cells have shown extreme resistance (Heller, 1948; Kivy, 1951; Oakberg \& Di Minno, 1960). After a sterilizing dose, such as 1000 rads, to a mouse testis all other cell types disappear but the Sertoli cells even appear to increase in number (Nebel \& Murphy, 1960). Primary spermatocytes are transformed to restitution cells and since the latter disappear after a few days it was conjectured by Nebel \& Murphy that the restitution cells may further transform into Sertoli cells and thus contribute to the increase, although these authors produced no evidence to prove this hypothesis.

There has been considerable argument whether this apparent increase in Sertoli cells is a real one, and various methods (Nebel \& Murphy, 1960; Clegg, 1963, investigating experimental cryptorchidism) have been used to try to

* Present address: Department of Anatomy, University of Liverpool. 
arrive at an accurate measure of the Sertoli cell population but with no clear conclusion.

Prompted by the conflicting results, we have made a renewed attempt to estimate their number before and at varying intervals after X-rays, making due allowances for the associated changes in testis size and the population of spermatogenic cells. Thus, the count is based on the product of three parameters, the number of Sertoli cell nuclei per unit volume of tubule, the proportion of testis occupied by tubules and the volume of the testis. The fate and life-span of spermatocytes labelled with $\left[{ }^{3} \mathrm{H}\right]$ thymidine is also followed.

\section{MATERIAL AND METHODS}

Mature male mice of a mixed crossbred population in the Paterson Laboratories were utilized. They were anaesthetized with intraperitoneal Nembutal (Abbott Laboratories Ltd) and their testes irradiated with a single dose of 1000 rads given in $8 \mathrm{~min}$. A 40 F.S.D. applicator was used. It was placed $5 \mathrm{~cm}$ above pressed wood using an irradiation factor of $300 \mathrm{kV}$ and $19.5 \mathrm{~mA}$. The mouse was placed lying on its back in a perspex box with a lead shield except in the region of the testes which were maintained in position by means of a rubber band around the abdomen of the mouse, and held against a perspex window. The box was then placed between the pressed wood and the applicator. Mice at each stage were killed at weekly intervals to a maximum of 4 weeks postirradiation. Both testes of each animal were fixed in 3:1 alcohol-acetic acid. Three dimensions were measured at right angles with the vernier callipers and the volume calculated as $\frac{4}{3} \pi r_{1}, r_{2}, r_{3}$. The testes were then weighed assuming a density of $\bumpeq 1$. As the volumes in $\mathrm{ml}$ and weights in $\mathrm{g}$ were found to be approximately equal, weight was taken as equivalent to the volume. The sections were cut from one testis at $5 \mu$ and stained with PAS and light green for Sertoli cell counts. Some slides were stained only with PAS for autoradiography using Kodak stripping film with an exposure of 3 weeks. Smears were made of the other testes and stained with acetic orcein after which they were subjected to the same autoradiographic technique.

Twenty male mice were injected with $1 \mathrm{ml}$ of $200 \mu \mathrm{c} / \mathrm{ml}$ of $\left[{ }^{3} \mathrm{H}\right]$ thymidine. They were divided into five groups of four and injected 12, 9, 6, 3 and 0 days before irradiation. One male of each of the above groups was unirradiated and used as control. The irradiated animals of each group were killed at 14, 21 and 28 days after labelling, when the spermatocytes would be expected, in unirradiated animals, to have transferred their label to spermatids, spermatozoa in the testis and spermatozoa in the epididymis, respectively.

\section{EXPLANATION OF PLATE 1}

Fig. 1. Unlabelled restitution cells obtained from irradiated spermatocytes. The most conspicuous difference from normal spermatids is their larger size. $\times 1250$.

FIG. 2. Spermatocytes labelled with $\left[{ }^{3} \mathrm{H}\right]$ thymidine transformed to labelled restitution cells after exposure to $X$-rays. $\times 1250$.

FIG. 3. Malformed labelled spermatozoa derived from labelled restitution cells after exposure to X-rays. $\times 1250$. 
PLATE 1
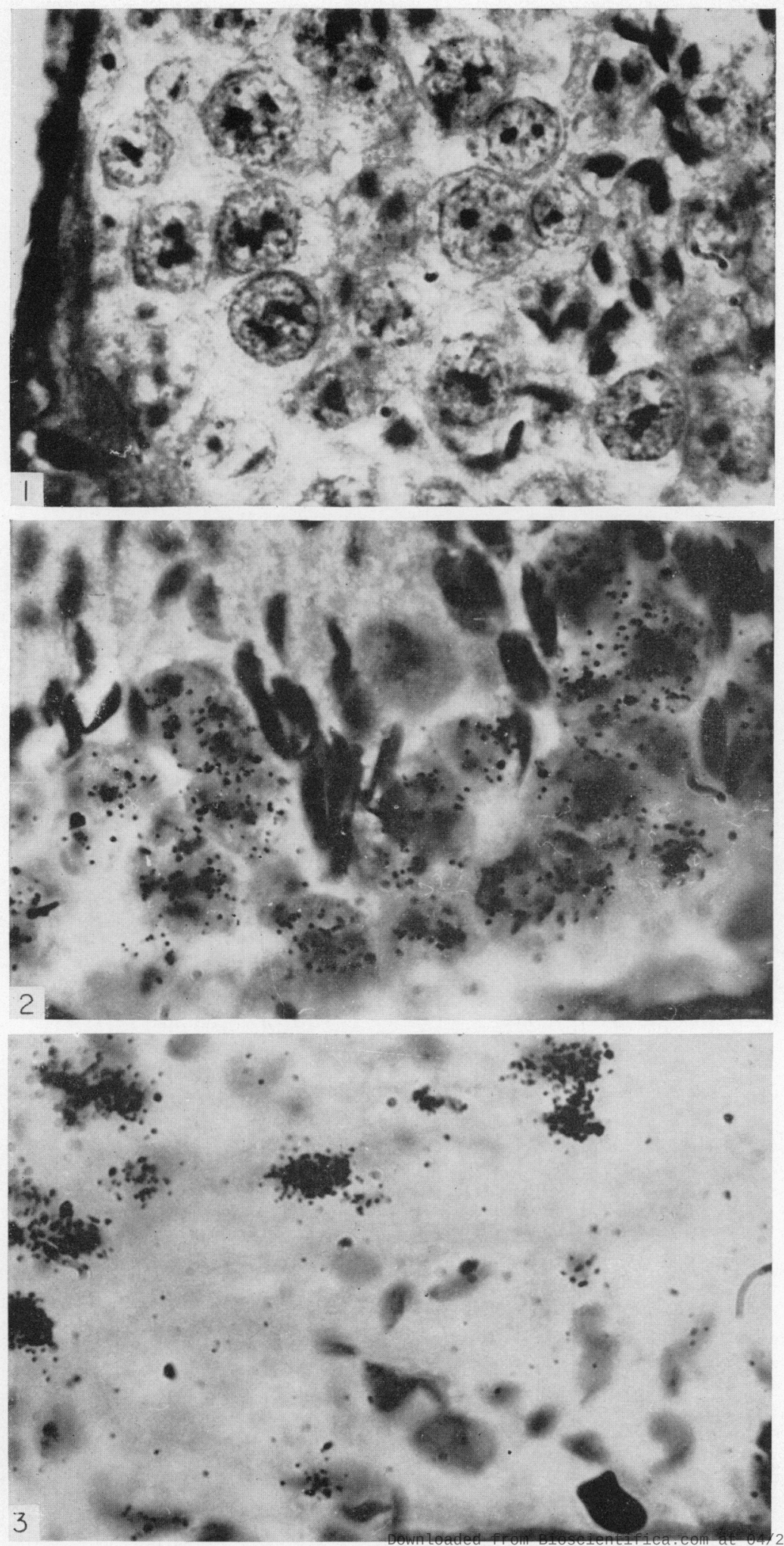
A quantitative estimation of the total number of Sertoli cells per testis was made in the following way:

The number of Sertoli nuclei was calculated for ten random tubule sections (any shape of cross section), $S$. The areas of the same tubules were measured with a camera lucida and converted to $\mathrm{cm}^{2}$ (factor $1.372 \times 10^{-5}$ ), $A$. The volumes of these tubule sections ( $A \times$ thickness of sections) in $\mathrm{cm}^{3}$ is $A \times 5 \times 10^{-4}$. Therefore the number of Sertoli cells per $\mathrm{cm}^{3}$ of tubule is

$$
\frac{S \times 10^{4}}{5 A}
$$

Weight of testis in $\mathrm{g}$ ( $\equiv$ volume in $\mathrm{cm}^{3}$ ), W. Proportion of testis occupied by tubules (mean of ten randomly selected areas), $T$. The volume of tubules in one testis is $W T$. Thus the total number of Sertoli cells

$$
S_{t}=\frac{S W T \times 10^{4}}{5 A}
$$

\section{RESULTS}

Table 1 summarizes the factors used in Sertoli cell estimation. As seen from Table 1 and Text-fig. 1, the number of Sertoli cells per unit volume of tubule

TABLE 1

\begin{tabular}{|c|c|c|c|c|c|c|}
\hline $\begin{array}{l}\text { Days post- } \\
\text { irradiation }\end{array}$ & $S / A$ & $\begin{array}{l}\text { Standard } \\
\text { error }\end{array}$ & $\begin{array}{c}\text { Testis } \\
\text { weight } \\
(\mathrm{g})\end{array}$ & $T$ & $\begin{array}{c}\text { Standard } \\
\text { error }\end{array}$ & $\begin{array}{c}\text { Total Sertoli } \\
\text { cells/testis } \\
\times 10^{-4} \\
\frac{S W T}{5 A}\end{array}$ \\
\hline $\begin{array}{l}\text { Control } \\
\text { Control } \\
\text { Control } \\
\text { Control }\end{array}$ & $\begin{array}{l}76,326 \\
54,893 \\
74,795 \\
66,193\end{array}$ & $\begin{array}{r}10,425 \\
3,208 \\
3,718 \\
3,674\end{array}$ & $\begin{array}{l}0.086 \\
0.091 \\
0.101 \\
0.098\end{array}$ & $\begin{array}{l}0.618 \\
0.634 \\
0.635 \\
0.635\end{array}$ & $\begin{array}{l}0.027 \\
0.038 \\
0.021 \\
0.040\end{array}$ & $\begin{array}{l}811 \\
634 \\
960 \\
823\end{array}$ \\
\hline $\begin{array}{c}\text { Mean of control } \\
2 \\
5 \\
8 \\
9 \\
11 \\
12 \\
14 \\
15 \\
18 \\
19 \\
22 \\
25 \\
28\end{array}$ & $\begin{array}{r}68,052 \\
51,467 \\
64,662 \\
76,691 \\
78,003 \\
86,824 \\
89,594 \\
101,185 \\
114,599 \\
129,106 \\
118,390 \\
246,329 \\
190,488 \\
189,613\end{array}$ & $\begin{array}{r}4,920 \\
4,520 \\
8,092 \\
3,281 \\
8,019 \\
12,714 \\
8,602 \\
7,946 \\
11,882 \\
17,350 \\
11,664 \\
20,120 \\
17,861 \\
24,494\end{array}$ & $\begin{array}{l}0.094 \\
0.112 \\
0.110 \\
0.083 \\
0.054 \\
0.067 \\
0.064 \\
0.065 \\
0.055 \\
0.048 \\
0.049 \\
0.032 \\
0.032 \\
0.039\end{array}$ & $\begin{array}{l}0 \cdot 631 \\
0 \cdot 502 \\
0 \cdot 483 \\
0 \cdot 478 \\
0 \cdot 444 \\
0 \cdot 477 \\
0.377 \\
0.386 \\
0.330 \\
0.315 \\
0.333 \\
0.276 \\
0.279 \\
0 \cdot 267\end{array}$ & $\begin{array}{l}0.004 \\
0.040 \\
0.029 \\
0 \cdot 016 \\
0 \cdot 027 \\
0 \cdot 031 \\
0.029 \\
0.018 \\
0.032 \\
0 \cdot 015 \\
0 \cdot 005 \\
0 \cdot 024 \\
0 \cdot 013 \\
0.015\end{array}$ & $\begin{array}{l}807 \\
579 \\
687 \\
609 \\
374 \\
556 \\
433 \\
508 \\
415 \\
391 \\
386 \\
435 \\
341 \\
395\end{array}$ \\
\hline
\end{tabular}

FACTORS USED IN TOTAL SERTOLI CELL ESTIMATION

increases dramatically. However, when factors such as tubule shrinkage (Text-fig. 3) and volume of testes (Text-fig. 2) are taken into account, instead of an increase of Sertoli cells there is an initial decrease in their number which gradually straightens out (Text-fig. 4). 


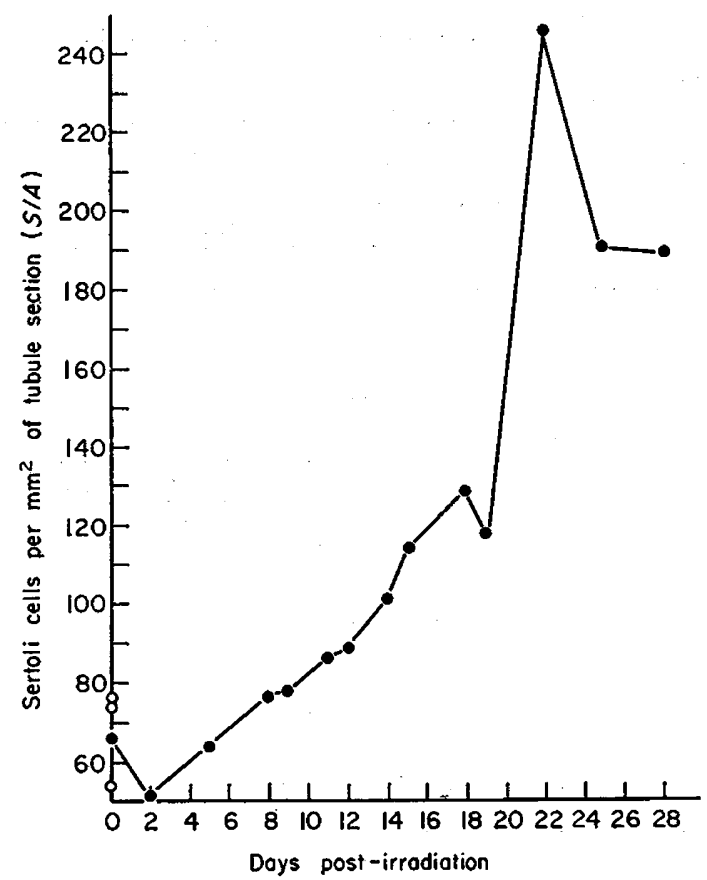

TEXT-FIG. 1. Shows, except for an initial decrease, a dramatic increase in Sertoli cells per unit volume of tubule after different intervals of irradiation.

The labelled spermatocytes are transformed to restitution cells (P1. 1, Fig. 1) regardless of the stage of meiotic prophase at which they were irradiated. Restitution cells (labelled and unlabelled; P1. 1, Figs. 1 and 2) are already

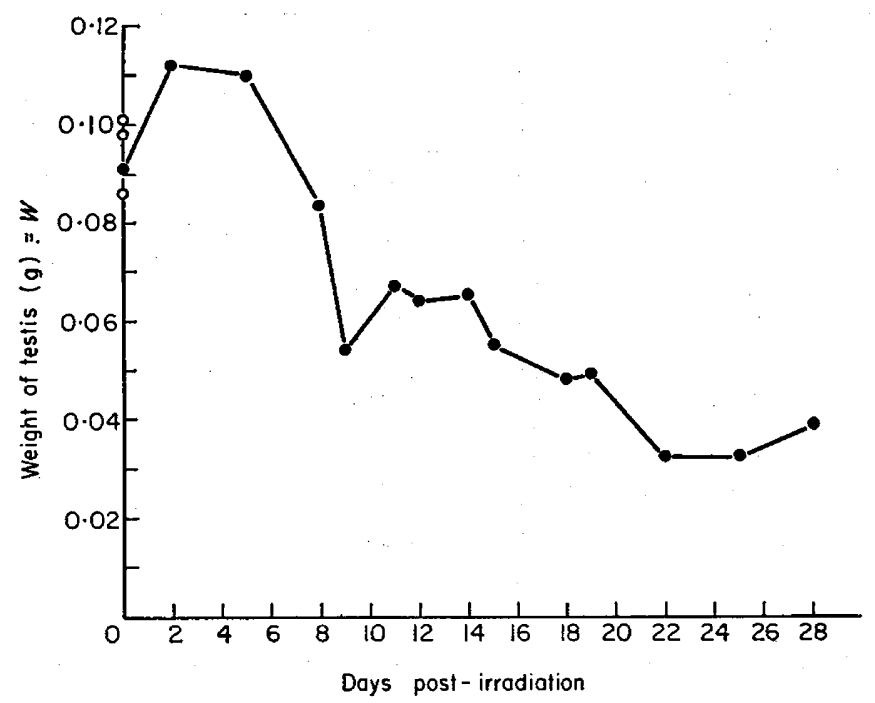

TEXT-FIG. 2. This graph illustrates the weight of testis in grams after 1000 rads of a single dose of X-rays. As seen from the graph there is a gradual fall in the weight of the testis as time after irradiation increases. 
present 2 days after irradiation, increase in frequency over the next few days and then steadily decline from 14 days after irradiation. Labelled restitution cells are replaced by labelled spermatozoa (Pl. 1, Fig. 3) at 21 days with a few

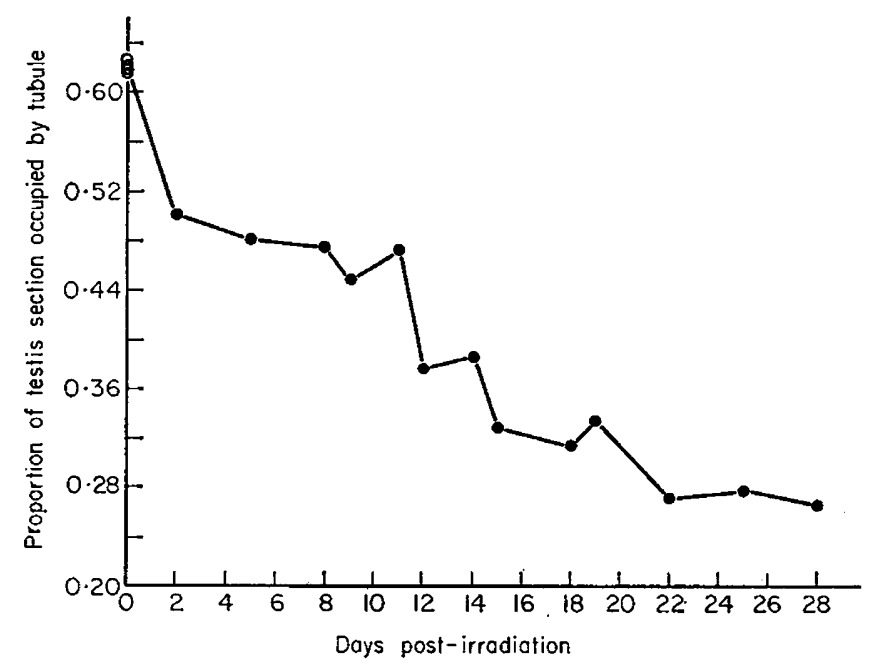

Text-Fig. 3. This graph shows that the proportion of testis occupied by the tubule decreases with time after irradiation and by about 28 days it is nearly $50 \%$ of control. The camera lucida technique was used to measure the amount of tubule present in the testis.

restitution cells remaining in some groups and by 28 days they are entirely eliminated.

On determining the distribution of grain count in cells before and after irradiation, the number of grains found to be present in spermatocytes, restitu-

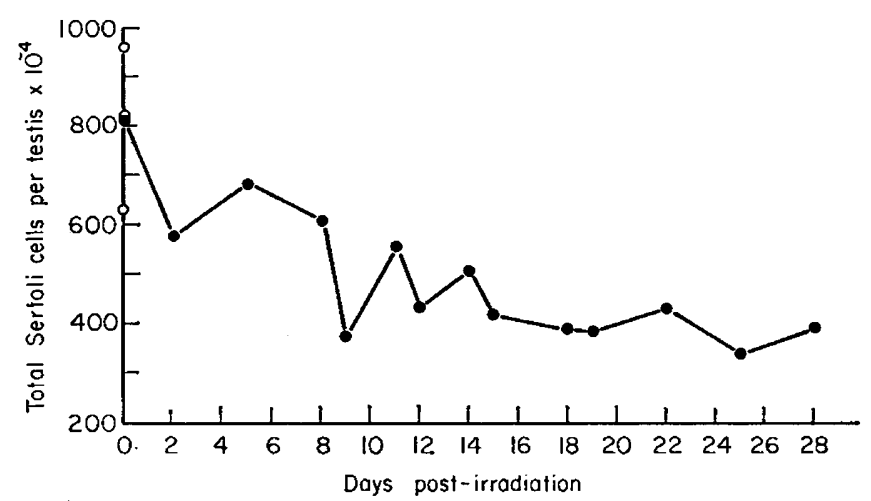

Text-Fig. 4. This graph shows that when all factors such as tubule shrinkage, volume of testis, and the Sertoli cells per unit volume of tubule are calculated to estimate the number of Sertoli cells in the testis, there is an initial reduction with a gradual stabilization of their number by 28 days after irradiation, the latest time at which they were counted.

tion cells and finally spermatozoa presented the same range (Table 2). It is therefore concluded that following 1000 rads the spermatocytes transform into restitution cells without undergoing a division, or if there is nuclear division it 
affects only a small proportion of the cells. These restitution cells then behave just like spermatids in metamorphosing into spermatozoa-like but malformed structures. No labelled Sertoli nuclei were found at any stage.

The results confirm those of Oakberg \& Di Minno (1960) in demonstrating that preleptotene spermatocytes, as measured by the low number of labelled restitution cells produced following the irradiation of labelled spermatocytes in that stage, are the most sensitive, and late pachytene and diplotene-diakinesis the most resistant of all the stages. In males irradiated in late pachytene and diplotene, there was a persistence of labelled restitution cells for 21 days and of

TABLE 2

THE GRAIN COUNTS PER SPERMATOCYTE, RESTITUTION CELL AND SPERMATOZOON

\begin{tabular}{c|c|c|c}
\hline \multirow{2}{*}{$\begin{array}{c}\text { Days from labelling to } \\
\text { killing (controls) }\end{array}$} & \multicolumn{2}{|c|}{ Grain count } & \\
\cline { 2 - 3 } & Mean & Standard error & \\
\hline 0 & 17.53 & 0.59 & Spell type counted \\
\hline 3 & 15.48 & 0.57 & Spermatocytes \\
6 & 18.00 & 0.62 & Spermatocytes \\
9 & 22.66 & 0.95 & Spermatocytes \\
\hline
\end{tabular}

\begin{tabular}{c|c|c|c|l}
\hline $\begin{array}{c}\text { Days from } \\
\text { labelling to } \\
X \text {-rays }\end{array}$ & $\begin{array}{c}\text { Days from } \\
\text { X-rays to } \\
\text { killing }\end{array}$ & \multicolumn{2}{|c|}{ Grain count } & Cell type counted \\
\cline { 2 - 3 } 12 & 2 & Mean & Standard error & \\
\hline 9 & 5 & 16.40 & 0.86 & Restitution cells \\
6 & 8 & 17.43 & 0.84 & Restitution cells \\
3 & 11 & 21.69 & 0.92 & Restitution cells \\
9 & 12 & 13.43 & 1.05 & Restitution cells \\
0 & 14 & 18.40 & 1.12 & Spermatozoa \\
6 & 15 & 13.93 & 1.02 & Restitution cells \\
3 & 18 & 11.96 & 1.45 & Spermatozoa \\
0 & 21 & 14.45 & 0.61 & Spermatozoa \\
& & 1.15 & Spermatozoa \\
\hline
\end{tabular}

The groups at intervals after 21 days have been excluded as the spermatozoa are in the epididymis at these stages.

labelled spermatozoa 28 days after labelling, indicating a delay in spermiogenesis relative to the normal time-table of spermiogenesis, as described by Oakberg (1955).

An examination was also made of the number of chromocentres (Feulgenpositive bodies) in the Sertoli cells in different groups (Text-fig. 5). Until about 14 days post-irradiation, the majority of Sertoli cells displayed the normal count of two. However, after about 14 days there was a sharp increase in Sertoli nuclei with only one chromocentre at the expense of nuclei with two. The percentage of nuclei with single chromocentres rises from $30 \%$ in unirradiated testes and less than 2 weeks after irradiation to over $50 \%$ (Text-fig. 5). This confirms the earlier observations of Bateman (unpublished), who also found that the increased frequency of nuclei with single chromocentres persisted for 100 
days, long after the spermatogenic elements in the testis had returned to normal. Bateman also showed that the volume of the single chromocentres was equal to the sum of the two chromocentres in the other nuclei, proving that the single

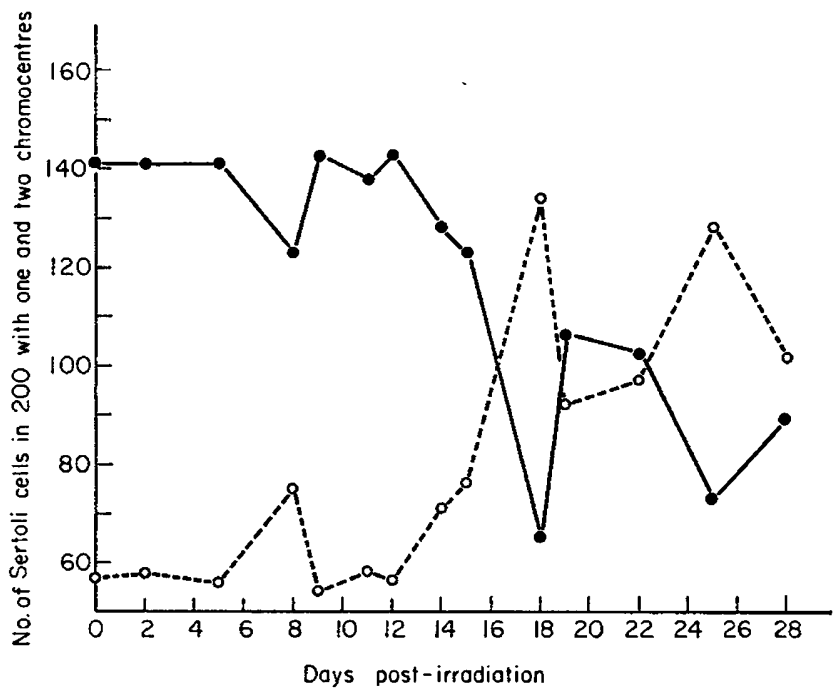

TexT-FIG. 5. The chromocentres in 200 Sertoli cells were enumerated in each animal in the control and irradiated testis. The dotted line represents Sertoli cells with one chromocentre, and the solid line with two. As seen from the graph, about 14 days after irradiation there is a sudden increase in Sertoli cells with one chromocentre and a simultaneous reduction of Sertoli cells with two chromocentres.

chromocentre was due to fusion. This fusion is apparently delayed until 14 days after irradiation.

\section{DISGUSSION}

The Sertoli cells act as an important mediator in the co-ordination of the normal process of spermatogenesis in the seminiferous epithelium (Lacy, 1960). However, as yet, there is no definite understanding of their function. Elftman (1950) found that the intimate attachment between the Sertoli cells and spermatids was accompanied by a marked increase in the rate of development of spermatogenic cells. Clegg \& Macmillan (1965) found the Sertoli cells to take up vital dyes, thus demonstrating their phagocytic and protective properties within the testes at times of injury and ill-health.

Their response to external factors such as X-rays, however, is still undetermined. Shaver (1953) and Oakberg \& Di Minno (1960) irradiated mice with sterilizing doses and found a marked resistance of Sertoli cells. Other workers even reported a hypertrophy of these cells and an increase in their number after X-rays (Bergonié \& Tribondeau, 1904; Wigoder, 1929; Nebel \& Murphy, 1960). This has been explained partly by their increased conspicuousness following the disappearance of all other cell-types from the seminiferous epithelium and partly by shrinkage of tubules which would increase the number of Sertoli cells per unit volume of tubule. Nebel \& Murphy (1960) after correcting 
the counts for tubule shrinkage found a $50 \%$ increase per tubule after 1000 rads of acute localized irradiation in mice. However, they could not clearly account for this increase as no mitosis was observed in them, nor could they think of any other possible origin except restitution cells.

The present enumeration of Sertoli cells showed that, though the number per unit volume of tubule increased, after using the correction factors there was an initial decrease which occurred during the 1st week of irradiation. This was followed by a stabilization of their numbers up to 28 days (the latest time at which observations were made). Perhaps during the massive shedding of other tubular elements many Sertoli nuclei are passively eliminated as well, and there being no mitosis in Sertoli cells, there is no possibility of replenishment.

Smears of testes showed a reduction in the mean number of chromocentres in Sertoli cells as shown by counts on 200 cells in smears from each testis. It may be that fusion of chromocentres is a non-specific response of most cells to irradiation (due to increased stickiness?) and that the small number (normally two) of chromocentres in Sertoli nuclei makes them particularly favourable material for the detection of this process. Another theoretical possibility is that the reduction of total count of Sertoli cells is selective against cells with more than one chromocentre. If all the $50 \%$ of Sertoli cells lost from the testis had two chromocentres the incidence of single chromocentres among those left would rise from $30 \%$ to $60 \%$, which is approximately what was found. One difficulty in this interpretation is that the loss of Sertoli cells takes place gradually over the first 2 weeks, whereas the percentage of single chromocentres changes suddenly between 15 and 18 days.

Abnormal forms of spermatozoa and spermatocytes have been observed by many previous workers (Wigoder, 1929, in mice; Maroulis, 1958, in man). Nebel \& Murphy (1960) studied the response of spermatocytes to X-rays and observed that they regressed from diakinesis to a resting phase without undergoing division, thus constituting a restitution cell. These cells increased 2 days after irradiation, their number reaching a maximum at 6 days and declining thereafter till their complete disappearance by 20 days. They also found many restitution nuclei migrating towards the basement membrane and thought that they might simulate the Sertoli cells. However, they did not follow the eventual fate of the restitution cells. It was to check this hypothesis that we labelled spermatocytes and followed their development by means of the label, after irradiating at different stages of meiosis. Irradiation at all stages produced labelled restitution cells, but by 21 days from labelling they gradually disappeared owing to their transformation to labelled spermatozoa, most of which were large and malformed. Thus the only labelled cells following irradiation of labelled spermatocytes were firstly restitution cells and secondly malformed spermatozoa. From these observations there is no evidence that the restitution cells develop into anything other than spermatozoa. In other words, they differentiate along the same pathway as spermatids.

Grain counts showed that the transition from spermatocyte to restitution cell to spermatozoon occurred without any nuclear division which would have halved the count at each division. Moreover, the transition followed the usual time-table of spermiogenesis except when late spermatocytes were irradiated. 
This produced a slowing down of metamorphosis, so that the labelled restitution nuclei and labelled spermatozoa were found 21 and 28 days respectively after labelling of preleptotene spermatocytes, which is somewhat longer than the normal time-table (Oakberg, 1955).

The rate of recovery of labelled restitution cells and spermatozoa from irradiated spermatocytes confirmed the conclusions of previous workers that early spermatocytes (preleptotene and zygotene) are most sensitive and late spermatocytes (approaching diakinesis) are least sensitive to X-rays. Thus the stages most susceptible to the killing effects of $\mathrm{X}$-rays are least sensitive in respect of retardation of development.

\section{ACKNOWLEDGMENTS}

Grateful thanks are extended to Dr L. G. Lajtha, Director of the Paterson Laboratories, for having offered the opportunity to work at his Laboratories and for his continual interest during the tenure of this work. Thanks are also due to Professor R. G. Harrison for his help and critical advice in the writing of this paper. The help of Mr D. J. Kidd and Mr D. L. Reeve (Department of Anatomy, University of Liverpool) in the preparation of the illustrations is gratefully acknowledged.

\section{REFERENCES}

Bergonie, J. \& Tribondeau, L. (1904) Actions des rayons $\mathrm{X}$ sur le testicle du rat blanc. C.r. Séanc. Soc. Biol. 57, 592.

GLEGG, E. J. (1963) Studies on artificial cryptorchidism. Morphological and quantitative changes in the Sertoli cells of the rat testis. 7. Endocr. $26,567$.

CLEGG, E. J. \& MAcmillan, E. W. (1965) The uptake of vital dyes and particulate matter by the Sertoli cells of the rat testis. F. Anat. 99, 219.

Elftman, H. (1950) The Sertoli cell cycle in the mouse. Anat. Rec. 106, 381.

Gunn, S., Clark, T. G. \& Anderson, A. D. (1960) The effect of X-irradiation on the morphology and function of rat testis. Am. F. Path. 37, 203.

HeLler, M. (1948) The histopathology of irradiation from external and internal sources. In: The Testis, p. 550. Ed. W. Bloom. McGraw-Hill, New York.

Jones, E. A. (1960) Number of spermatogonia after X-irradiation of the adult rat. Int. F. Radiat. Biol. 2, 157.

KIVY, E. (1951) The immediate and prolonged effect of single dose X-radiation on the testes and germinal epithelium of the golden hamster (Cricetus auratus). F. Morph. 88, 573.

LACY, D. (1960) Light and electron microscopy and its use in the study of factors influencing spermatogenesis in the rat. $\mathcal{F l} R$. microsc. Soc. 79, 209.

Marouus, B. G. (1958) Pathologic spermatogenesis. Unusual large teratoid spermatozoa. Fert. Steril. 9, 227.

NeBEL, B. R. \& MURPhy, C. J. (1960) Damage and recovery of mouse testis after 1,000 $\mathrm{r}$ acute localised $\mathrm{X}$-irradiation with reference to restitution cells, Sertoli cell increase, and Type A spermatogonia recovery. Radiat. Res. 12, 626.

OAKBerg, E. F. (1955) Sensitivity and time of degeneration of spermatogenic cells irradiated in various stages of maturation in the mouse. Radiat. Res. 2, 369.

OAKBerg, E. F. \& Di Minno, R. L. (1960) X-ray sensitivity of primary spermatocytes of the mouse. Int. F. Radiat. Biol. 2, 196.

Shaver, S. L. (1953) X-irradiation injury and repair in the germinal epethelium of male rats. 1. Injury and repair in adult rats. Am. F. Anat. 92, 391.

Wigoder, S. B. (1929) The effect of X-rays on the testis. Br. F. Radiol. 2, 213. 